\section{ONOMARVEIN}

Revista semestral de lingüística, filología y traducción
PONTIFICIA UNIVERSIDAD CATÓLICA DE CHILE FACULTAD DE LETRAS

\title{
Tracking down phrasal verbs: the case of up and down ${ }^{1}$
}

\author{
Andreea Rosca \\ Centro Universitario de la Defensa \\ Academia General Militar \\ España
}

\section{Yvonne Baker de Altamirano}

Centro Universitario de la Defensa

Academia General Militar

España

\section{(c) $(\mathrm{i}) \bigodot_{\mathrm{BY}}$}

Andreea Rosca: Centro Universitario de la Defensa, Academia General Militar, España.

| Correo electrónico: arosca@unizar.es

Yvonne Baker de Altamirano: Centro Universitario de la Defensa, Academia General Militar, España.

| Correo electrónico: baker@unizar.es 
ONOMÁZEIN 34 (diciembre de 2016): 296-321

Andreea Rosca e Yvonne Baker de Altamirano:

Tracking down phrasal verbs: the case of up and down

\begin{abstract}
Since the frequency of phrasal verbs is register-specific, it is essential for L2 learners to be exposed to the most productive phrasal verbs in their field of study. Thus, English for Police learners should become familiar and practise the most recurrent phrasal verbs in the context of crime and police investigative work. In this study we determine the frequency and meaning extensions of phrasal verbs with the particles up and down in a spoken corpus of English for the Police on the basis of which we also generate teaching materials for L2 trainee police officers. This research extends McCarthy and O'Dell's (2004) scope of analysis by encompassing not only phrasal verbs related to criminal behavior but also to the procedures followed by the police in the investigation of a crime.
\end{abstract}

Keywords: phrasal verbs; cognitive linguistics; frequency; English for the Police. ${ }^{1}$

\footnotetext{
1. The research on which this paper is based has been financed by the Spanish Ministry of Economy and Competitiveness, grant no. FFI2013-43593-P.
} 
ONOMÁZEIN 34 (diciembre de 2016): 296-321

Andreea Rosca e Yvonne Baker de Altamirano: Tracking down phrasal verbs: the case of up and down

\section{Introduction}

Phrasal verbs should form part of L2 learners' essential linguistic repertoire since they are one of the most productive and creative resources of the English language (Cubillo, 2002). Many authors have studied the challenges that non-native learners of English face in the acquisition of these linguistic phenomena: (1) the sheer number of phrasal verbs; (2) their polysemy; (3) their structural and syntactic complexity (e.g. the transitive/intransitive dichotomy, the post-verb or post-direct object position); (4) crosslinguistic differences ${ }^{2}$ (e.g. the non-universality of phrasal verbs, Liao and Fukuya, 2004); and (5) inadequate textbook presentation (for further discussion see Sinclair, 1989: iv; Alejo et al., 2010b). As pointed out by Gardner and Davies (2007: 347), "learners will encounter, on average, one [phrasal verb] in every 150 words of English they are exposed to". Apart from their ubiquity, English speakers possess the ability to coin new phrasal verbs with ease (Bolinger, 1971). Since their prolific nature can confuse L2 learners as to which ones to learn, linguists are called upon to determine their usefulness regarding the learners' objectives, learning contexts and their frequency of occurrence. Due to the fact that the frequency of phrasal verbs varies across registers, L2 learners should become familiar with the most recurrent phrasal verbs in their own field of study. Also, teaching materials will often fail to provide an accurate reflection of real language in that the contents of a syllabus are based on "the author's gut-level impressions and anecdotal evidence of how speakers and writers use the language" (Biber and Reppen, 2002: 200). English textbooks usually present learners with overwhelming lists of phrasal verbs, together with their corresponding definitions, and the practice relies heavily on matching or gap-fill exercises which require rote learning

\footnotetext{
${ }^{2}$ Alejo (2010a) provides us with a list of six main factors that Second Language Acquisition (SLA) experts have found to influence the acquisition of phrasal verbs: (1) nativeness (Siyanova and Schmitt, 2007; Ishii and Sohmiya, 2006); (2) language distance effects-L1 Dutch learners (Hulstijn and Marchena, 1989) avoid phrasal verbs less than L1 Hebrew learners (Dagut and Laufer, 1985); (3) developmental sequence-advanced students display less avoidance than students at lower levels (Liao and Fukuya, 2004); (4) context of acquisition-Siyanova and Schmitt (2007) have found that both EFL and ESL learners encounter difficulties in acquiring phrasal verbs; (5) idiomaticity-phrasal verbs that are more opaque are likely to be avoided (Dagut and Laufer, 1985); and (6) task effects-L2 learners avoid phrasal verbs less in more controlled tasks, such as multiple choice tests (Liao and Fukuya, 2004).
} 
without any conceptual consideration (Darwin and Gray, 1999; Gardner and Davies, 2007; Tyler and Evans, 2004).

The purpose of this article is to determine the frequency and meaning extensions of phrasal verbs with the particles up and down in a spoken corpus of English for the Police on the basis of which to generate teaching materials for L2 trainee police officers. For our purposes, we have compiled a corpus of spoken dialogues taken from the script of the first four seasons of the American TV series Castle. Without stage directions, character names, and all incidental language, the corpus amounts to 504, 124 running words. With respect to the analysis of phrasal verbs, we have adopted Rudzka's (2003) cognitive motivations for the particles up and down since her approach combines both linguistic verbal input and visual imagery for meaning extensions (see Gehring and Toglia, 1989; and Stevick, 1996, for psychological evidence on visualization in education). Furthermore, empirical studies have shown that a CL (Cognitive Linguistics)-inspired proposal to phrasal verbs can enhance their comprehension, and retention as well as knowledge transference from learnt to novel phrasal verbs (Boers, 2000; Condon, 2008; Condon and Kelly, 2002; Kövecses and Szabó, 1996; Kurtyka, 2001). Our research study intends to fill the gaps related to phrasal verbs about police investigative work. McCarthy and O'Dell's (2004) textbook comprises only phrasal verbs referring to criminal behaviour, such as beat sb up, break into/out of sth, hold up $s t h / s b$, put sb up to sth, to name but a few. On the basis of corpus analysis, we suggest an alternative list of phrasal verbs that also indicate the steps taken by the police in the investigation of a crime. Thus, detectives have to verify information (run sth down), take suspects to the police station to be either interrogated or arrested (pick $s b u p$ ), pursue further investigative leads (follow up on sth/with $s b$ ), reduce the list of suspects (narrow sth down), and close an investigation (wrap up/sew up a case).

This research is divided into two different parts. The first part introduces the reader to the theoretical foundations for our study and the relevant methodological considerations whereas the second part focuses on the analysis and explanation of corpus examples as well as the pedagogical activities for L2 learners. Section 2 deals with the definition of a phrasal verb as a concept adopted for this study. Section 3 centers on the description of the procedures that have been followed to compile the data. In section 4 we illustrate the top 25 phrasal verbs with the particles up and down. The 
ONOMÁZEIN 34 (diciembre de 2016): 296-321

Andreea Rosca e Yvonne Baker de Altamirano:

Tracking down phrasal verbs: the case of up and down

discussion of the meaning extensions for these two particles is covered in sections 4.1 and 4.2 respectively. In section 4.3 we propose an outline of data-driven activities for trainee police officers studying English as a second language. The last section comprises all the findings of our investigation and highlights several proposals for further research.

\section{What is a phrasal verb?}

What qualifies as a phrasal verb has always been a topic that has sparked considerable debate. Bolinger (1971: 6) reflects on this lack of consensus in linguistics by pointing out that "being or not being a phrasal verb is a matter of degree". Along similar lines, Gardner and Davies (2007: 341) claim that "linguists and grammarians struggle with nuances of phrasal verb definitions" and that such distinctions are of little instructional value for the average second language learner. Most English grammars agree that phrasal verbs are idiomatic verbs in which a verb is paired with one or more prepositions or particles and whose meaning is not strictly predictable from its component parts. The unpredictability of phrasal verbs seems to be given by particles since the meanings of verbs are less controversial. This study will adopt a CL perspective according to which the meanings of particles actually form a radial network of related senses stretching from central (literal) to more peripheral (metaphorical) meanings (cf. Lindner, 1981; Lakoff, 1987; Rudzka-Ostyn, 2003). The central meaning of a preposition/particle refers to spatial locations or movements whereas the peripheral senses which are abstract are usually derived from the concrete, spatial sense "by means of generalization or specialization of meaning or by metonymic or metaphoric transfer" (Cuyckens and Radden, 2002: xiii). For example, Lakoff (1987) analyzes the relations between the spatial meanings and their metaphorical extensions of the preposition over. Regarding spatial senses, five different senses are identified: (1) the 'above and across' sense (e.g. The plane flew over); (2) the 'above' sense (e.g. The helicopter is hovering over the hill); (3) the 'covering' sense (e.g. The board is over the hole); (4) the 'reflexive' sense (e.g. Roll the log over); (5) the 'excess' sense (e.g. The bathtub overflowed). The metaphorical senses are the following: (1) metaphorical extensions of the 'above and across' sense (e.g. I noticed that he skated over the topic of 
redundancies); (2) metaphorical extensions of the 'above' sense (e.g. I had the Open University exam hanging over me); (3) metaphorical extensions of the 'covering' sense (e.g. They tried to paper over the crime); (4) metaphorical extensions of the 'reflexive' sense (e.g. override a decision/order); (5) metaphorical extensions of the 'excess' sense (e.g. He was bubbling over with enthusiasm). Moreover, Rudzka-Ostyn (2003) claimed that with the exception of a few static verbs (e.g. be, sit, hold, etc.) the verbs that combine with particles are mostly verbs of motion, either physical (e.g. run, break, throw, etc.), or abstract (e.g. think, sell, buy, refer, etc.). The verbs that indicate physical motion can also be used to express abstract, non-visible changes (e.g. run up a hill vs. run up expenses; throw out old clothes vs. throw a person out of a club).

The choice of the CL perspective on phrasal verbs is motivated by two main reasons. First, the systematicity of particle meanings that is contributed by CL greatly facilitates the comprehension of phrasal verbs for L2 learners. By "uncovering the iconic structure of language" (Pütz, 2007: 1145) CL raises L2 learners' awareness of the connections between the different meanings of a particle and how they can be extrapolated to other contexts. Similar to mind maps, radial networks used in CL are based on the assumption that our memory is associative, not linear. The mind remembers key words and images more easily than sentences. Second, several empirical studies have confirmed the effectiveness of didactic applications of CL theory for the teaching of phrasal verbs (Boers, 2000; Kövecses and Szabó, 1996; Condon, 2008). The identification of the link between the literal and more idiomatic meanings of particles is likely to foster faster acquisition and longer retention.

\section{Methodology and data gathering}

There are several corpus-based studies that have focused on the frequency of phrasal verbs in English (Biber et al., 1999; Gardner and Davies, 2007; Trebits, 2009; Liu, 2011; Lee, 2015). Biber et al.'s (1999) pioneering study relies on four corpora representative of four different registers extracted from US and UK sources: conversation, academic writing, newspapers and fiction. This work also examines the frequencies of different lexical classes such as nouns, verbs, adjectives and adverbs. Both Gardner and Davies (2007) and Trebits (2009) look at the frequency of phrasal 
ONOMÁZEIN 34 (diciembre de 2016): 296-321

Andreea Rosca e Yvonne Baker de Altamirano: Tracking down phrasal verbs: the case of up and down

verbs mainly in written English, i.e. the first one in the British National Corpus (BNC) and the second one in EU documents. Along the lines of Biber et al., Liu's research (2011) provides a cross-English variety examination by comparing the BNC with the COCA and examines the frequency of phrasal verbs across five registers in American English, viz. spoken, fiction, magazine, newspapers, and academic writing. The study that comes closest to our research area is probably Lee's (2015) that investigates and compares the frequency of phrasal verbs in an academic spoken corpus and a casual conversation corpus, namely the Michigan Corpus of Academic Spoken English (MICASE) and the Friends sitcom transcripts (season 1 - season 10). Although our aim is also to examine the frequency of phrasal verbs in spoken English, we focus on a specific context of ESP, namely English for the Police.

Since it is difficult to obtain real police-spoken data due to privacy issues (cf. Basturkmen, 2010), we have compiled our own corpus, stripped of stage directions, character names and all incidental language, leaving a total of 504,124 words. The choice of the TV series Castle is motivated by its growing viewer popularity (around 10 or 12 million viewers) not only in the US but also in Europe.

Drawing from McCarthy and O'Dell's (2004) work on crime-related phrasal verbs, in our study we have extended the scope of analysis from phrasal verbs denoting criminal actions (e.g. beat sb up, hold sth/sb up) to phrasal verbs referring to evidence (emergence, compilation, elimination) and actions carried out by the police in their investigative work. The phrasal verbs found in our corpus were divided into two categories, viz. those related or unrelated to the criminal context, which resulted in a total of 886 and 903 tokens respectively. For instance, verbs like grow up (e.g. You had a lot of imaginary friends growing up, didn't you? [S03E20]), wait up (e.g. I would say don't wait up but you'll be asleep by eleven [S01E02]) or break down (They said their car broke down and they needed a ride [S02E09]) were regarded as unrelated to the context of crime.

In table 1 we have gathered the most prototypical collocations with those phrasal verbs related to a criminal context. 
ONOMÁZEIN 34 (diciembre de 2016): 296-321

Andreea Rosca e Yvonne Baker de Altamirano:

Tracking down phrasal verbs: the case of $u p$ and down

Table 1. Prototypical collocations with crime-related phrasal verbs

\begin{tabular}{|c|c|}
\hline Phrasal verb & Prototypical collocations \\
\hline end up & dead, near death, murdered, in jail, in hospital, missing, killing (name of victim) \\
\hline pick up & $\begin{array}{l}\mathrm{X} \text { (name of crime suspect), murder weapon, gun, scent, money, shipment, } \\
\text { investigation }\end{array}$ \\
\hline track down & $\begin{array}{l}\text { X (usually noun phrases, names or personal pronouns referring to a victim/suspect: } \\
\text { him, her, them, you, this dealer, that accomplice, this mysterious woman), IP, } \\
\text { accounts, checks }\end{array}$ \\
\hline run down & $\begin{array}{l}\text { cell number, alibi, client list, reports, mail threats, whereabouts, money } \\
\text { withdrawals, make and model, break in, a lead, names, address, receipts, purchases }\end{array}$ \\
\hline put down & knife, gun, hands, weapon, him, you (meaning 'kill someone') \\
\hline $\begin{array}{l}\text { come up (usually } \\
\text { intransitive) }\end{array}$ & $\begin{array}{l}\text { with a sketch, clean, negative, missing, empty ('inability to find new leads'), } \\
\text { contusions, name, something ('new leads') }\end{array}$ \\
\hline narrow down & $\begin{array}{l}\text { chemical signature, the suspects, whereabouts, the list, search, the field, it (referring } \\
\text { to the list of suspects) }\end{array}$ \\
\hline set up & $\begin{array}{l}\text { X (usually noun phrases, names, or personal pronouns referring to a victim: her, me, } \\
\text { him, them, this kid), dummy phone lines, fake identity, protection detail, the war } \\
\text { room, a sting, a canvass, on the office }\end{array}$ \\
\hline $\begin{array}{l}\text { go down (usually } \\
\text { intransitive) }\end{array}$ & hostage exchange, crimes, with/without a fight, for murder, deal, abduction, murder, \\
\hline $\begin{array}{l}\text { turn up (usually } \\
\text { intransitive) }\end{array}$ & $\begin{array}{l}\text { dead, murdered, a security camer, ketamine and oxycodone, in your possession, } \\
\text { anything, nothing (referring to new leads in a case) }\end{array}$ \\
\hline $\begin{array}{l}\text { open up (usually } \\
\text { intransitive) }\end{array}$ & police orders (referring to the opening of a door), an investigation \\
\hline take down & $\begin{array}{l}\mathrm{X} \text { (noun phrases, names or personal pronouns referring to a victim or a } \\
\text { suspect/criminal: his victim, the target, their suspect, the Spolanos, him, you, them) }\end{array}$ \\
\hline cover up & the/a crime, her/the/another murder, it (her body), the truth \\
\hline $\begin{array}{l}\text { dig up (also } \\
\text { intransitive) }\end{array}$ & police report, the bodies, three bodies, associates ('suspects') \\
\hline give up & your alibi, myself, his partner, information, the badge, names of a suspect (Danton) \\
\hline $\begin{array}{l}\text { clean up (also } \\
\text { intransitive) }\end{array}$ & $\begin{array}{l}\text { all types of dirt, the/his mess (figurative meaning referring to legal problems or } \\
\text { crimes) }\end{array}$ \\
\hline shut down & it (bomb), the whole operation, the investigation, the case, us/them (illegal business) \\
\hline $\begin{array}{l}\text { follow up (also } \\
\text { intransitive) }\end{array}$ & a lead, on a lead, with the victim's sister, with a think tank \\
\hline make up & that story/stories, a lie ('false testimony'), a sketch \\
\hline $\begin{array}{l}\text { sit down (usually } \\
\text { intransitive) }\end{array}$ & police orders in the interrogation room \\
\hline blow up & that ATM video, this one section (of a video), my apartment, half a city block \\
\hline beat up & her, him, that mugger \\
\hline $\begin{array}{l}\text { calm down } \\
\text { (usually } \\
\text { intransitive) }\end{array}$ & police orders in tense situations \\
\hline lock up & $\begin{array}{l}\text { me, him, you (personal pronouns or names referring to suspects/criminals), in } \\
\text { prison }\end{array}$ \\
\hline pull up & old case files, cell phone traffic, copy of police reports, his ID, any recent activity \\
\hline
\end{tabular}


ONOMÁZEIN 34 (diciembre de 2016): 296-321

Andreea Rosca e Yvonne Baker de Altamirano: Tracking down phrasal verbs: the case of up and down

Also, the phrasal verbs in our corpus occupy different positions on the cline of prototypicality. Thus, there is no doubt that phrasal verbs like lock up (e.g. [...] I can lock him up in prison for the rest of his life [S04E21]) or go down (e.g. Young Mr. Addison is going down for both murders [E03E19]) are more prototypical than make up (e.g. That guy does not have the improv skills to make up a lie like that [S03E16]) or sit down (e.g. And I've got a witness that places you at the murder scene. So sit down! [S04E13]). This can be explained by the fact that the semantic meaning of the former is automatically associated with a criminal context (i.e. it is normally law offenders that are imprisoned or confined). As for the latter, the association with crime is cued by the surrounding context (e.g. rendering false testimony is considered obstruction of justice and the action of sitting down is an order given by a law enforcer to a criminal in the interrogation room).

Furthermore, in our corpus the same phrasal verb can be categorized as either related or unrelated to crime depending on the nature of the agent or that of the affected entity. Consider the phrasal verb give up which means 'to yield control or possession of an entity'. In the sentence To be young, beautiful, talented. No woman wants to give it up [S02E03], it is evident that no crime is involved since what is described is a universal truth, i.e. women dread losing their physical attractiveness and intellectual competence. However, in this sentence Well, maybe he's old school? Didn't want to give up the badge he built his career on [S03E07], the same phrasal verb is used in a criminal context in which a police officer is required by protocol to surrender their duty weapon and badge upon termination of employment. The same holds true for phrasal verbs with the particle down. Compare the sentence Remember that power outage a couple weeks ago that shut down the subway? [S03E12] with Susan runs towards the ticking bomb to try to shut it down [S01E08]. In both sentences the phrasal verb shut down has the same meaning, viz. 'to stop operating'. However, the first example refers to a non-criminal incident where an accidental fault in the electrical power system disrupts service along subway lines. The second utterance clearly involves a criminal setting, in which an agent tries to defuse a bomb probably planted in a public place. Another less prototypical meaning for shut down is 'to stop talking' as in We don't have any proof that he did it. I mean, what if he shuts down and doesn't talk? [S02E03]. In 
this sentence we can see that the detectives cannot make progress in their investigations if a suspect refuses to cooperate and reveal useful information.

These fine-grained distinctions indicate that counting the frequency of phrasal verbs can be a rather arduous and challenging task. Because of these subtle differences in meaning we preferred to examine the examples one by one thereby ensuring the accuracy and reliability of the data. The last stage entailed watching all 81 episodes so as to be able to contextualize the data, spot potential mistakes in our analysis and reclassify phrasal verbs.

\section{Frequency results and discussion}

Table 1 presents the list of the 25 most productive phrasal verbs with the particle up and down in our corpus. Their frequency of occurrence is given in raw numbers and percentages accompanied by their cumulative counts. As announced in the previous section, we have encountered a total of 886 tokens of phrasal verbs connected with the context of crime and police investigative work. From this, we have identified a total of 164 lexical verb-types for both up and down, more precisely 127 lexical verb-types for up and 37 for down respectively. The greater occurrence of up was only to be expected since previous studies on the order of productivity of adverbial particles have shown that $u p$ is the most recurrent particle in English whereas down appears lower down on the productivity list (cf. Sinclair, 1989; Biber et al., 1999). In addition, the cumulative percentages displayed in table 2 reveal that only the top 14 phrasal verbs account for over $50 \%$ of all phrasal verbs whereas the top 25 phrasal verbs constitute more than $60 \%$ of all phrasal verbs in the corpus. Given that the overall size of the corpus is of 504,124 tokens, we can estimate that an L2 learner is likely to find almost two phrasal verbs related to crime in 1000 words of text.

Table 2. The top 25 phrasal verbs with the particles up and down in the corpus

\begin{tabular}{|l|l|l|l|l|}
\hline Rank & Phrasal verb & Raw frequency & $\begin{array}{l}\text { \% of all PVs with } \\
\text { up \& down in the } \\
\text { corpus }\end{array}$ & Cumulative \% \\
\hline 1 & end up & 63 & 7.11 & 7.11 \\
\hline 2 & pick up & 54 & 6.09 & 13.20 \\
\hline 3 & track down & 52 & 5.86 & 19.07 \\
\hline
\end{tabular}


ONOMÁZEIN 34 (diciembre de 2016): 296-321

Andreea Rosca e Yvonne Baker de Altamirano:

Tracking down phrasal verbs: the case of up and down

\begin{tabular}{|l|l|l|l|l|}
\hline 4 & run down & 42 & 4.74 & 23.81 \\
\hline 5 & put down & 39 & 4.40 & 28.21 \\
\hline 6 & come up & 33 & 3.72 & 31.94 \\
\hline 7 & narrow down & 25 & 2.82 & 34.76 \\
\hline 8 & set up & 24 & 2.70 & 37.47 \\
\hline 9 & go down & 20 & 2.25 & 39.72 \\
\hline 10 & turn up & 20 & 2.25 & 41.98 \\
\hline 11 & open up & 19 & 2.14 & 44.13 \\
\hline 12 & take down & 19 & 2.14 & 46.27 \\
\hline 13 & cover up & 18 & 2.03 & 48.30 \\
\hline 14 & dig up & 17 & 1.91 & 50.22 \\
\hline 15 & give up & 17 & 1.91 & 52.14 \\
\hline 16 & clean up & 16 & 1.80 & 53.95 \\
\hline 17 & shut down & 15 & 1.69 & 55.64 \\
\hline 18 & follow up & 14 & 1.58 & 57.22 \\
\hline 19 & make up & 13 & 1.46 & 58.69 \\
\hline 20 & sit down & 13 & 1.46 & 60.15 \\
\hline 21 & blow up & 12 & 1.35 & 61.51 \\
\hline 22 & beat up & 10 & 1.12 & 62.64 \\
\hline 23 & calm down & 10 & 1.12 & 63.76 \\
\hline 24 & lock up & 10 & 1.12 & 64.89 \\
\hline 25 & pull up & 10 & 1.12 & 66.02 \\
\hline
\end{tabular}

If we compare our data with Liu's (2011) findings, we see that seven of our most prolific phrasal verbs also appear among the top 25 phrasal verbs in the COCA (e.g. pick up, come up, set up, give up, make up, end up, and sit down). However, a closer look at their frequency of occurrence in the spoken register of the COCA indicates that the rank orders of these seven phrasal verbs do not exactly match ours (COCA: come up, pick up, end up, set up, give up, sit down, and make up vs. our data: end up, pick up, come up, set up, give up, make up, and sit down). Also, by comparing our findings with Lee's (2015) study we can notice that only three of our most frequent phrasal verbs are listed among the top 25 phrasal verbs in the sitcom Friends (e.g. pick up, come up, and make up). Trebits (2009: 477) points out that ESP course designers and materials developers should focus specifically on those phrasal verbs that are productive in the ESP field but not so much in general English. In our case, English for Police textbooks and materials should provide ample practice on phrasal verbs like beat up, cover up, dig up, lock up, track down, run down, and narrow down. 
ONOMÁZEIN 34 (diciembre de 2016): 296-321

Andreea Rosca e Yvonne Baker de Altamirano:

Tracking down phrasal verbs: the case of up and down

\subsection{Meaning extensions of $u p$}

Once we counted the tokens and verb-types, we used Rudzka's (2003) cognitive motivations to identify the literal and figurative meaning extensions of the particles up and down in our corpus. In this section we will only focus on the phrasal verbs with up, which have been grouped into five semantic clusters:

1) UP: position at a high place or moving up to a higher one-dig up (literal meaning), get up, keep (hands) up, mount up, put (entity) up, saddle up, stand up.

2) UP (to): aiming at or reaching a goal, an end, a limit-back sth up to sth else, catch up with sb, follow up, give sb up to sb else (deliver to authorities), go up against (lack of connectivity), grab up, hit up, hook up with sb, lead up to sth, line up with sth, live up to sth, lock up, match up sth with sth else, pick up, put sb up to sth, snatch up.

3) UP: moving to a higher degree, value or measure-back up, blow up (enlarge picture), change up, dirty up, gather up (crew), lawyer up, mob up, offer up, partner up, pile up, shoot up (drugs), shore up, stack up, straighten up, switch up.

4) UP: higher up is more visible, accessible, known-bring up (issue), bring up (on a screen), call sth up (screen), chat up, clear up, come up (appear), come up with sth, cook up (drugs), dig up (information), draw up (document), dredge up, give up (information), kick up, look up, make up (falsify; create), mock up, pop up, pull up (screen), read up on sb, rig up, round up, run sb up, scare up, set sth up (create), set sb up (bring about a bad situation for sb, make them become a suspect), show up, size up, spark up, stir up, study up on sb, throw up (red flags), turn up, write up.

5) UP: covering an area completely/reaching the highest limit-bang up, beat up, blow up (explode), bollix up, break up (fight), bust up, check up, clean up, cover up, cut up, dress up, divvy up, end up, fill up (cell), finish up, freeze up, give up (an activity), hack up, hold up, hole up, mess up, mix sb up with sb else, open up, pack up, package up, pay up, screw up, seal up, sew up, show up (murdered), shut up, slice up, stir up (crime scene-destroy), tangle up, tape up, 
tear up, tense up, tie up, tune up, turn up (dead), wind up, wipe up, wrap up (case), wrap up (dead body).

The first meaning extension which is also the central meaning conveyed by the particle up involves literal motion of an entity from a lower to a higher place. This meaning extension is best instantiated in our corpus by the phrasal verb get up which can mean 'to rise to one's feet' (e.g. Get up! Put your hands in the air. Hands on your head, now! [S04E15]). Apart from spatial upward motion, the particle up can also denote literal or abstract motion towards a goal or limit where the goal can be extended to events or emotional states. A clear example is the phrasal verb back sth up to sth else with the meaning 'to rewind a video' (e.g. He already has a blood lip. (sic) Can you back that up to earlier? [S04E08]). Another semantic extension associated with the particle up is abstract motion to a higher degree, value or measure. In the sentence Take a day. Shore this up. And if there's sufficient evidence I'll contact LAPD [S03E22], the phrasal verb shore up indicates that detectives need solid evidence on which to build a case and justify a prosecution. The particle up can also express greater visibility, access to knowledge or emerging since when an entity is located or moves to a higher level or location, it is easier to be noticed (e.g. No, but tox results turned up ketamine and oxycodone [S04E17]). The fourth meaning extension, viz. covering an area completely or reaching the highest limit includes verbs that refer to the idea of completing or finishing something (e.g. Getting that body was supposed to sew our case up, not blow it apart [S04E03]), damaging and destroying (e.g. During my set that night, someone smashed my bike's taillight, banged up the fenders [...] [S02E20]), stopping, delaying and disrupting (e.g. He got held up, by some junkie probably. Shot dead over eighty bucks [S04E02]) and dividing or separating (e.g. A masked vigilante on the loose hacking people up [S04E02]). It is also important to point out that a phrasal verb can have different meaning extensions. For example, blow up can exemplify both the third semantic extension (e.g. 'to enlarge picture' [...] tech was able to blow up and enhance that ATM video [S03E20]) and the fifth one (e.g. 'to explode' You provided him with enough C4 to blow up half a city block [S03E12]).

Also in connection with the number of meanings, authors like Trebits (2009) and Liu (2011) have shown that the cross-register distribution of the meanings of a phrasal 
ONOMÁZEIN 34 (diciembre de 2016): 296-321

Andreea Rosca e Yvonne Baker de Altamirano: Tracking down phrasal verbs: the case of up and down

verb can vary. Thus, in ESP the number of word-senses associated with the most frequent phrasal verbs is considerably lower compared to general English. For instance, in our corpus the second most frequent phrasal verb pick up has six different senses and twelve in general English. Moreover, it is usually the most productive phrasal verbs that are the most polysemous. Thus, the phrasal verb pick up has the following meanings: (1) take into custody (e.g. Maybe we ought to pick Chloe up to see if she backs the story [S01E02]); (2) collect something, usually in an illegal transaction (e.g. They said they needed passports. I sent Roger to make the drop and pick up the money [S02E24]); (3) capture on film (e.g. Cam never picks her up again [S01E02]); (4) clean up (e.g. It takes real presence of mind to put five bullets into a man's chest and then keep your cool long enough to pick up after yourself [S02E24]); (5) resume after a break (e.g. You know, it's late, and I'm kinda tired. How about we pick this up in the morning? [S02E20]); and (6) notice a smell or sound (e.g. Dogs picked up a scent, traced it to the west side of the cemetery, but then they lost it there [S04E01]).

Lastly, some of these phrasal verbs are so closely related in meaning that they can be used interchangeably in certain contexts. This is the case of phrasal verbs like dig up and dredge up, which have the meaning 'unearth evidence' (e.g. You are digging up her past, darling, without her permission [S01E10]; You dredged up my past for you, Castle [S02E01]). Other similar examples are kick up and stir up meaning 'create trouble', grab up, pick up, and snatch up meaning 'take into police custody', end up and wind up meaning 'come to a finish', or show up, turn up, and pop up meaning 'appear', among many others.

\subsection{Meaning extensions of down}

We shall now look at the semantic clusters for the phrasal verbs with the particle down:

1) DOWN: movement from a higher to a lower place-bang down, get down, knock down, put down (weapon), run down (list), shoot down (plane), sit down.

2) DOWN: decrease in intensity, quality, quantity, size, degree, value, activity, status, strength-back down, calm down, crack down on sth/sb, cut 
ONOMÁZEIN 34 (diciembre de 2016): 296-321

Andreea Rosca e Yvonne Baker de Altamirano: Tracking down phrasal verbs: the case of up and down

down (reduce), narrow down, narrow sth down to sth else, shake down, slow down.

3) DOWN: reach a goal, completion, extreme limit down the scale-boil down to sth/sb, break sth down to sth else, bring down, burn down, chase down, come down to sth, cut down (kill), go down (die), go down (be put in prison), gun down, hunt down, lock down, nail down, pin sb down on sth, put down (kill), scrub down, shoot down, shut down, strike down, take down, track down, track down sth to sb, wipe down, write down ${ }^{3}$.

A clear example of the first meaning extension is the phrasal verb shoot down with the meaning 'make a plane literally fall to the ground by firing weapons at it' (e.g. He worked for Doctors Without Borders in Uganda until his helicopter was shot down by guerilla forces a year ago [S04E20]). On a continuum literal downward movement extends into abstract downward movement, such as decrease in amount, strength, importance, intensity, etc. Consider the sentence So we fed her descriptors in the DMV database and got it narrowed down to two women [S03E13]. In this example the phrasal verb narrow sth down to sth else shows how detectives have to reduce a list of suspects to identify a criminal. The third meaning extension, namely reaching a goal or the lowest limit on an abstract scale, gathers verbs that refer to the idea of suppressing or destroying something (e.g. His marriage failed, his daughter fell into drugs, and he was just gunned down in his own apartment [S03E14]), defeating something (e.g. They asked him to develop a nonnuclear military strategy that would bring down the Soviet Union [S04E16]), stopping, failing or not working properly (e.g. We were working to locate them when Iron Gates shut down the investigation [S04E01]), or specifying something very exactly (e.g. There might be security cam footage that might nail down how long she was gone from her apartment [S02E23]).

\footnotetext{
${ }^{3}$ Rudzka separates out verbs of eating and writing (e.g. gulp down, jot down) into a fourth category presumably because of their physical verticality. However, writing something down can also be related to pinning something down or locking something down in the sense that you wish to hold or retain some information and therefore it is apposite to include it in the third extension.
} 
Furthermore, it has to be said that some of these phrasal verbs do not illustrate very clear-cut concepts and thus, it was quite difficult to pin down their meaning extension. A case in point is the phrasal verb bring down, which according to Rudzka (2003) indicates a decrease in status. Nevertheless, for us it refers to the extreme limit down the scale of power since it does not mean to undermine a government but to destroy it, topple it. Other phrasal verbs that posed problems for us were knock down and bang down as in Having to wait this long to tell me how you banged down the door [S02E18] and Did you have to knock down my door? [S04E17]. These two verbs are fuzzy concepts since it is not clear if the emphasis should be put on the literal movement of a door falling to the ground or the outcome of a violent action, i.e. the destruction of an entity. We also disagree with Rudzka's decision to classify shut down as 'decrease in activity' (e.g. Vice raided a few of them looking for a reason to shut them down [S02E16]). For us, it is clear that this phrasal verb refers to the end of an illegal activity. What is more, we have noticed that in this case Rudzka's taxonomy was somewhat influenced by the context (e.g. Because of the recession GM will be forced to shut down several factories) since the synonymous phrasal verb close down is listed in 'extreme limit down the scale' (e.g. All the factories and mines closed down and the place became a ghost town).

Finally, the polysemy of the phrasal verbs with down is less productive than in the case of phrasal verbs with up. For instance, one of the most frequent phrasal verbs with down, viz. go down, has only three different meanings: (1) happen (crime) (e.g. Hostage exchange goes down at midnight [S02E18]); (2) be sent to prison (e.g. Young Mr. Addison is going down for both murders [S03E19]); and (3) lose, be defeated or even die (e.g. She was strangled, but she went down with a fight [S04E20]) ${ }^{4}$.

Table 3. Comparison of the meaning extensions for up and down

\begin{tabular}{|l|l|l|l|l|l|}
\hline \multicolumn{2}{|c|}{ Meaning extension } & \multicolumn{2}{|c|}{ UP } & \multicolumn{2}{|c|}{ DOWN } \\
\hline $\begin{array}{l}\text { 1) Position at a } \\
\text { high place or }\end{array}$ & $\begin{array}{l}\text { 2) Movement } \\
\text { from a higher }\end{array}$ & $\begin{array}{l}\text { 1) Get up! Put your } \\
\text { hands in the air. }\end{array}$ & 2)- & 1)- & $\begin{array}{l}\text { 2) He worked for Doctors } \\
\text { Without Borders in }\end{array}$ \\
moving up to a & to a lower & Hands on your head, & & & $\begin{array}{l}\text { Uganda until } \\
\text { his }\end{array}$ \\
\hline
\end{tabular}

\footnotetext{
${ }^{4}$ For an in-depth quantification and exemplification of the meanings of the top 25 phrasal verbs in our corpus see the table in Appendix I.
} 
ONOMÁZEIN 34 (diciembre de 2016): 296-321

Andreea Rosca e Yvonne Baker de Altamirano:

Tracking down phrasal verbs: the case of up and down

\begin{tabular}{|c|c|c|c|c|c|}
\hline higher one & place & now! [S04E15] & & & $\begin{array}{l}\text { helicopter was shot down } \\
\text { by guerilla forces a year } \\
\text { ago }[\mathrm{S} 04 \mathrm{E} 20]\end{array}$ \\
\hline \multicolumn{2}{|c|}{$\begin{array}{l}\text { 3) Aiming at or reaching a goal, } \\
\text { an end, a limit }\end{array}$} & \multicolumn{2}{|c|}{$\begin{array}{l}\text { 3) He already has a blood lip. } \\
\text { (sic) Can you back that up to } \\
\text { earlier? [S04E } 08]\end{array}$} & \multicolumn{2}{|l|}{ 3) - } \\
\hline $\begin{array}{l}\text { 4) Moving to a } \\
\text { higher degree, } \\
\text { value or } \\
\text { measure }\end{array}$ & $\begin{array}{l}\text { 5) Decrease in } \\
\text { intensity, size, } \\
\text { degree, value, } \\
\text { etc. }\end{array}$ & $\begin{array}{l}\text { 4) Take a day. Shore } \\
\text { this up. And if there's } \\
\text { sufficient evidence I'll } \\
\text { contact LAPD } \\
\text { [S03E22] }\end{array}$ & 5) - & 4) - & $\begin{array}{l}\text { 5) So we fed her } \\
\text { descriptors in the DMV } \\
\text { database and got it } \\
\text { narrowed down to two } \\
\text { women [S03E13]. }\end{array}$ \\
\hline \multicolumn{2}{|c|}{$\begin{array}{l}\text { 6) Higher up is more visible, } \\
\text { accessible, known }\end{array}$} & \multicolumn{2}{|c|}{$\begin{array}{l}\text { 6) No, but tox results turned up } \\
\text { ketamine and oxycodone } \\
\text { [S04E17] }\end{array}$} & \multicolumn{2}{|l|}{ 6) - } \\
\hline $\begin{array}{lr}\text { 7) } & \text { Reaching } \\
\text { the } & \text { highest } \\
\text { limit } & \end{array}$ & $\begin{array}{l}\text { 8) Reaching } \\
\text { the extreme } \\
\text { limit down the } \\
\text { scale }\end{array}$ & $\begin{array}{l}\text { 7) You provided him } \\
\text { with enough C4 to } \\
\text { blow up half a city } \\
\text { block [S03E12] }\end{array}$ & 8) - & 7) - & $\begin{array}{l}\text { 8) They asked him to } \\
\text { develop a nonnuclear } \\
\text { military strategy that } \\
\text { would bring down the } \\
\text { Soviet Union [S04E16] }\end{array}$ \\
\hline
\end{tabular}

Table 3 summarizes the different meaning extensions for up and down that have been discussed so far throughout the article. This table also includes illustrative examples for each and every meaning extension.

\subsection{Pedagogical activities}

Based on the findings of our work, we propose several activities that English for Police teachers can implement in their classes. We have combined various strategies: (1) inductive instruction which encourages learners to guess the meaning of a phrasal verb out and from context (viz. concordance lines from a corpus); (2) deductive approach according to which learners are explicitly shown the systematicity of phrasal verbs in the context of crime and police investigative work, and (3) communicative approach which enables learners to discuss either in pairs or groups the scenarios cued by phrasal verbs (e.g. compiling evidence, arresting, negotiating with criminals) or to conduct a briefing on a homicide and present the case in front of the class.

1) Inductive instruction.

a) In groups of three try to work out the literal/spatial and/or figurative/metaphorical meanings of the following phrasal verbs: end up, pick 
ONOMÁZEIN 34 (diciembre de 2016): 296-321

Andreea Rosca e Yvonne Baker de Altamirano: Tracking down phrasal verbs: the case of up and down

up, track down, run down, and put down. Can you find any connections with the context of crime and police investigative work?

b) Next, check your predictions against the uses listed in the concordance lines below. Distinguish between literal and figurative meanings.

1) How does he end up dead the same day this guy rides in his cab? [S03E16]

2) That was the DOJ. That fifty thousand dollar wire transfer bounced through the United Arab Emirates before it ended up in Ryker's account. It came from the Dubai branch of a Swiss bank. [S03E24]

3) After your first failed attempt to steal the fist you decided to hire a better class of thief. Unfortunately, he ended up killing Brian Hayes in the process.[S04E05]

4) Police picked him up in Atlantic City for charges of disorderly conduct.[S02E23]

5) Only Benny makes off with the money before the blackmailer's had a chance to pick it up [S02E23]

6) We just got word on the security footage at the airport. Cameras did pick up a blue, late model Malibu leaving the area but its license plate was blacked out. [S03E24]

7) So you being the expert veteran of dozens of crime scenes decided to pick up the murder weapon to what? Insure that we had your prints? [S03E01]

8) CSU tracked down where the photo was processed.[S04E17]

9) Ryan. Track down the delivery guy to see when this was delivered and whether anyone else was up here when he brought it. [S02E06]

10) Oh, we got uniforms running down all show employees who could've had access to the studio to take that photo. [S02E20]

11) Yeah. Hey, Esposito, run down Winston Wellesley's alibi. Talk to doormen, chauffeurs, the whole gamut. [S02E08]

12) Put down the gun or I swear I'll blow his head off! [S03E11]

13) If Lockwood's going after this third cop, he's still in town. You both know what he's capable of. You get a chance to put him down, do not hesitate.[S03E24]

c)Drawing from the concordance lines above, indicate the aspects these phrasal verbs refer to, namely evidence (emergence/compilation/destruction), criminal behavior or police activity. Fill in the table with your findings. 


\begin{tabular}{|l|l|l|}
\hline $\begin{array}{l}\text { end up - finally be in an } \\
\text { incriminating place }\end{array}$ & $\begin{array}{l}\text { pick up - collect something } \\
\text { in an illegal transaction }\end{array}$ & $\begin{array}{l}\text { run down - quickly read } \\
\text { everything on a list }\end{array}$ \\
\hline & & \\
\hline & & \\
\hline
\end{tabular}

2) Deductive instruction.

The teacher provides explicit verbal explanations of the cognitive motivations of the particles up and down which should be accompanied by Rudzka's (2003: 75-120) visual schemas for their meaning extensions. After that, students are asked to classify the phrasal verbs in examples 1-13 according to Rudzka's meaning extensions and to discuss their opinions with a partner. In what follows we include a brief example of the explicit instructions for the particle down.

A phrasal verb is composed of a verb and a particle (up, down). Particles can have both literal or spatial and figurative or metaphorical meanings. The literal meaning is the basic/central meaning and the figurative meanings are considered its extensions. 1) For example, the basic meaning of the particle down is spatial movement of an entity from a higher to a lower place. Consider the sentence The guerilla forces shot down the helicopter. The particle down tells us that the helicopter fell from the sky to the ground. 2) This particle can also express abstract downward movement, such as decrease in amount, intensity, importance, etc. Take the following example The detectives narrowed the suspects down to two women. Thus, the reduction of a list of suspects is seen as gradual downward motion on the scale of amount. 3) Another meaning extension is reaching a goal or the lowest limit on an abstract scale, usually something negative. In the sentence He was gunned down in his own apartment the particle down indicates the death of a person.

3) Information gap activity.

You are part of a team of police detectives. Conduct a briefing with your partners to inform one another about the progress that has been made in this investigation. Take turns to set up a murder board for this case. Add information on potential suspects, eye witnesses and create a timeline of events leading up to the victim's murder. Pin down the identity of the murderer by sharing your opinions with your partners. After 
wrapping up the case display your murder board and present the case in front of the class. Allow your classmates to guess the identity of the murderer ${ }^{5}$.

\begin{abstract}
Role card 2 Assistant detective A
You picked up Lance Newman, a protester who was arrested five times for violent agitation. Last month, he beat up a Congressman who voted against a fishing ban. He also painted the word 'murderer' with fake blood on the Congressman's car. He also wrote several violent letters which were sent to Wilder's home address. Although all evidence is pointing in his direction it might be that someone is trying to set him up for murder. Lance Newman admitted having vandalized Wilder's apartment on Thursday. That night he also heard the victim fighting violently with a woman inside his apartment. You ran down Newman's alibi for Sunday night and found out that he used the automated ticket booth at the theatre at the time of the murder. You also got a copy of Wilder's date book in which you found several entries for a woman named Natasha, probably his girlfriend. Wilder's assistant confirmed that he and Natasha Piper had started dating recently and claimed that Natasha was quite violent: she once tore up a studio set at a shooting session for an advertisement. You believe the uniforms should follow up on Natasha.
\end{abstract}

\title{
5. Conclusions and suggestions for further research
}

In brief, our study contributes to the field of English for Specific Purposes, more precisely English for the Police, by determining the usefulness of phrasal verbs connected to crime and police investigative work on the basis of their frequency of occurrence. It has extended McCarthy and O'Dell's (2004) scope of analysis by encompassing not only phrasal verbs related to criminal behavior but also to the procedures followed by the police in the investigation of a crime. It has also been demonstrated that phrasal verbs constitute a multi-faceted class in that the same phrasal verb can be categorized as related or unrelated to crime depending on the nature of the agent or that of the affected entity (e.g. give up, shut down). We have relied on Rudzka's (2003) cognitive motivations to identify the literal and figurative semantic extensions of the particles up and down (e.g. get up, shoot down vs. shore up, narrow down). Lastly, based on our research findings we proposed various pedagogical activities for English for Police learners which blend inductive and deductive instruction with communicative approaches to language learning and teaching.

As for the future development of this research project, several suggestions should be considered. Firstly, our corpus of data could be further expanded to cover other

\footnotetext{
${ }^{5}$ The full set of role cards can be obtained by writing to the authors.
} 
ONOMÁZEIN 34 (diciembre de 2016): 296-321

Andreea Rosca e Yvonne Baker de Altamirano: Tracking down phrasal verbs: the case of up and down

adverbial pairings such as in-out, on-off in relation to crime. This would certainly offer English for Police students a more global picture of the productivity of phrasal verbs in the context of crime and police investigative work. Secondly, we should compare and contrast our findings from the American TV series with a corpus culled from a British crime series. Finally, the validity of this CL-inspired pedagogy should be tested by incorporating it into a language learning program which could actually reveal if English for Police learners benefit from such an approach and if they are able to transfer their knowledge about learnt phrasal verbs to new ones used in the same context.

\section{Bibliographic references}

Alejo GonZÁlez, Rafael, 2010a: "Making sense of phrasal verbs: A cognitive linguistic account of L2 learning" in Jeannette LiTTLEMORE and Constanze JUCHEMGrundmann (eds.): Applied Cognitive Linguistics in Second Language Learning and Teaching. AILA Review 23, Amsterdam: John Benjamins, 50-71.

Alejo GonzÁlez, Rafael, Ana PiQuer Píriz and Guadalupe Reveriego Sierra, 2010b: "Phrasal verbs in EFL course books" in Sabine DE KNOP, Frank BoERS and Antoon DE RYCKER (eds.): Fostering Language Teaching Efficiency through Cognitive Linguistics, Berlin / New York: Mouton de Gruyter, 59-78.

BASTURKMEn, Helen, 2010: Developing courses in English for specific purposes, London: Palgrave Macmillan, 71-87.

BIBER, Douglas, et al., 1999: Longman Grammar of Spoken and Written English, London: Longman.

BIBER, Douglas, and Randi REPPEN, 2002: "What does frequency have to do with grammar teaching?", SSLA 24, 199-208.

BOERS, Frank, 2000: "Metaphor awareness and vocabulary retention", Applied Linguistics 21, 553-571.

Bolinger, Dwight, 1971: The Phrasal Verb in English, Cambridge, Massachusetts: Harvard University Press, 99-104.

Condon, Nora, and Peter Kelly, 2002: "Does Cognitive Linguistics have anything to offer English language learners in their efforts to master phrasal verbs?", I.T.L.137$138,205-231$. 
ONOMÁZEIN 34 (diciembre de 2016): 296-321

Andreea Rosca e Yvonne Baker de Altamirano: Tracking down phrasal verbs: the case of up and down

Condon, Nora, 2008: "How cognitive linguistic motivations influence the learning of phrasal verbs" in Frank BOERS and Seth LindstromberG (eds.): Cognitive Linguistic Approaches to Teaching Vocabulary and Phraseology, Berlin: Mouton de Gruyter, 133-158.

Cubillo, María Carmen, 2002: "Phrasal and prepositional verbs in specialized texts: a creative device, Ibérica 4, 95-111.

CUYCKENS, Hubert, and Günter RADDEN, 2002: "Introduction” in Hubert CUYCKENS and Günter Radden (eds.): Perspectives on Prepositions, Tübingen: Niemeyer, ixxvii.

DAGUT, Menachem, and Batia LAUfER, 1985: “Avoidance of phrasal verbs: A case for contrastive analysis", Studies in Second Language Acquisition 7(1), 73-79.

DARWIN, Clay, and Loretta GRAY, 1999: “Going After the Phrasal Verb: An Alternative Approach to Classification", Tesol Quarterly 33(1), 65-83.

Gardner, Dee, and Mark Davies, 2007: "Pointing Out Frequent Phrasal Verbs: A Corpus-Based Analysis", TESOL Quarterly 41(2), 339-359.

GEHRING, Robert, and Michael TOGLIA, 1989: "Recall of pictorial enactments and verbal descriptions with verbal and imagery study strategies", Journal of Mental Imagery 13(2), 83-98.

Hulstijn, Jan, and Elaine MarchenA, 1989: “Avoidance: Grammatical or semantic causes?", Studies in Second Language Acquisition 11(3), 241-255.

ISHII, Yasutake, and Kiyoko SOHMIYA, 2006: "On the semantic structure of English. Spatial particles involving metaphors" in Asako Yoshitomi (ed.): Readings in a Second Language Pedagogy and Second Language Acquisition: In Japanese Context, Amsterdam: John Benjamins, 381-402.

KÖVECSES, Zoltán, and Peter SzABÓ, 1996: "Idioms: A view from cognitive semantics", Applied Linguistics 17, 326-335.

KURTYKA, Andrzej, 2001: “Teaching English Phrasal Verbs: A Cognitive Approach” in Martin PÜtz, Susanne NiemeIERand René Dirven (eds.): Applied Cognitive Linguistics vol. II. Language Pedagogy, Berlin / New York: Mouton de Gruyter, 2954.

LAKOFF, George, 1987: Women, Fire and Dangerous Things: What Categories Reveal about the Mind, Chicago: The University of Chicago Press. 
ONOMÁZEIN 34 (diciembre de 2016): 296-321

Andreea Rosca e Yvonne Baker de Altamirano: Tracking down phrasal verbs: the case of up and down

LEE, Ju-Young, 2015: "The use of English phrasal verbs in American spoken corpora", International Journal of Language Studies 9(2), 27-48.

LiAO, Yan, and Yoshinori FukUYA, 2004: “Avoidance of Phrasal Verbs: The Case of Chinese Learners of English", Language Learning 54(2), 193-226.

Lindner, Susan, 1981: A Lexico-Semantic Analysis of English Verb Particle Constructions with OUT and UP. Ph.D. diss. San Diego: University of California.

LIU, Dilin, 2011: “The Most Frequently Used English Phrasal Verbs in American and British English: A Multicorpus Examination”, Tesol Quarterly 45(4), 661-688.

MCCARThy, Michael, and Felicity O’Dell, 2004: English phrasal verbs in use, Cambridge: Cambridge University Press.

PÜTZ, Martin, 2007: "Cognitive Linguistics and Applied Linguistics" in Dirk Geeraerts and Hubert Cuyckens (eds.): The Oxford Handbook of Cognitive Linguistics, Oxford: Oxford University Press, 1139-1159.

RudzkA-Ostyn, Brygida, 2003: Word Power: Phrasal Verbs and Compounds, The Hague: Mouton de Gruyter.

SinclaIR, John (ed.), 1989: Collins Cobuild Dictionary of Phrasal Verbs, London: Collins Publishers.

TreBiTs, Anna, 2009: “The most frequent phrasal verbs in English language EU documents-A corpus-based analysis and its implications”, System 37, 470-481.

TYLER, Andrea, and Vyvyan Evans, 2004: "Applying cognitive linguistics to pedagogical grammar: The case of over" in Michel ACHARD, and Susanne NIEMEIER (eds.): Cognitive linguistics, second language acquisition, and foreign language teaching, Berlin: Mouton de Gruyter, 257-280.

SiYANOVA, Anna, and Norbert SchMiTt, 2007: "Native and non-native use of multiword vs. one-word verbs", IRAL 45, 119-139.

SteVick, Earl, 1996: Memory, Meaning and Method: A View of Language Teaching, 2nd edition, Boston, MA: Heinle and Heinle Publishers.

\section{Appendix I}

Exemplification of the meanings of the top 25 phrasal verbs in our corpus

\begin{tabular}{l|l|l|l} 
Rank & PV & Number of meanings & Example
\end{tabular}




\begin{tabular}{|c|c|c|c|}
\hline 1 & end up & $\begin{array}{l}\text { 1) reach or come to an end, } \\
\text { usually unpleasant }\end{array}$ & $\begin{array}{l}\text { How does he end up dead the same day this } \\
\text { guy rides in his cab? [S03E16] }\end{array}$ \\
\hline 2 & pick up & $\begin{array}{l}\text { 1)take into custody; 2) collect } \\
\text { something, usually in an illegal } \\
\text { transaction; 3) capture on film; } \\
\text { 4) clean up; 5) resume after a } \\
\text { break; 6) notice a smell or } \\
\text { sound }\end{array}$ & $\begin{array}{l}\text { 1) Maybe we ought to pick Chloe up to see if } \\
\text { she backs the story [S01E02]); } \\
\text { 2) They said they needed passports. I sent } \\
\text { Roger to make the drop and pick up the } \\
\text { money [S02E24]); } \\
\text { 3) Cam never picks her up again [S01E02]); } \\
\text { 4) It takes real presence of mind to put five } \\
\text { bullets into a man's chest and then keep your } \\
\text { cool long enough to pick up after yourself } \\
\text { [S02E24]); } \\
\text { 5) You know, it's late, and I'm kinda tired. } \\
\text { How about we pick this up in the morning? } \\
\text { [S02E20]); } \\
\text { 6) Dogs picked up a scent, traced it to the } \\
\text { west side of the cemetery, but then they lost it } \\
\text { there [S04E01]). }\end{array}$ \\
\hline 3 & track down & $\begin{array}{l}\text { 1) find } \mathrm{sb} / \mathrm{sth} \text { by searching or } \\
\text { looking for information in } \\
\text { several different places }\end{array}$ & $\begin{array}{l}\text { CSU tracked down where the photo was } \\
\text { processed.[S04E17] }\end{array}$ \\
\hline 4 & run down & $\begin{array}{l}\text { 1) quickly read everything on a } \\
\text { list }\end{array}$ & $\begin{array}{l}\text { Oh, we got uniforms running down all show } \\
\text { employees who could've had access to the } \\
\text { studio to take that photo. [SO2E20] }\end{array}$ \\
\hline 5 & put down & $\begin{array}{l}\text { 1) place sth onto a surface; 2) } \\
\text { kill someone like an animal. }\end{array}$ & $\begin{array}{l}\text { 1) Put down the gun or I swear I'll blow his } \\
\text { head off! [S03E11] } \\
\text { 2) You don't want to do this, Mitch. (she } \\
\text { inches closer) Because I will have to put you } \\
\text { down. Do you understand?[S04E01] }\end{array}$ \\
\hline 6 & come up & $\begin{array}{l}\text { 1) appear; 2) fail to achieve a } \\
\text { desired result; 3) produce or } \\
\text { provide sth that people want; } 4 \text { ) } \\
\text { suggest or think of an idea or } \\
\text { plan (think of a better alibi). }\end{array}$ & $\begin{array}{l}\text { 1) But we've been over their lives with a fine } \\
\text { tooth comb. He's never come up once. } \\
\text { [S04E01] } \\
\text { 2) We've got teams sweeping buildings near } \\
\text { both crime scenes and so far we've come up } \\
\text { empty. [S04E09] } \\
\text { 3) We have the waitress working with an } \\
\text { artist to see if we can come up with a sketch } \\
\text { of the goateed man to use on a canvass. } \\
\text { [S04E10] } \\
\text { 4) Given the fact that you have two prior } \\
\text { felony sales on your sheet you should } \\
\text { probably come up with something better } \\
\text { pretty quick. [S01E03] }\end{array}$ \\
\hline 7 & $\begin{array}{l}\text { Narrow } \\
\text { down }\end{array}$ & $\begin{array}{l}\text { 1) reduce a number or a list of } \\
\text { things }\end{array}$ & $\begin{array}{l}\text { So we fed her descriptors in the DMV } \\
\text { database and got it narrowed down to two } \\
\text { women [S03E13]. }\end{array}$ \\
\hline 8 & set up & $\begin{array}{l}\text { 1) make sb be blamed wrongly, } \\
\text { especially for something illegal; } \\
\text { 2) build a structure or put it in a } \\
\text { particular place; 3) establish, } \\
\text { found; 4) take up positions; 5) } \\
\text { prepare sth for use, especially } \\
\text { by putting the different parts of } \\
\text { it together }\end{array}$ & $\begin{array}{l}\text { 1) Everyone on his payroll, including the } \\
\text { dirty cop that set me up [S02E21] } \\
\text { 2) Okay, why would they set up dummy } \\
\text { phone lines and give phony } \\
\text { recommendations? [S02E10] } \\
\text { 3) Set up a protection detail for the wife and } \\
\text { the kid. [S02E08] } \\
\text { 4) Castle and I will set up at the paper in } \\
\text { case he shows. [SO2E14] } \\
\text { 5) They're setting up the war room.[S02E17] }\end{array}$ \\
\hline
\end{tabular}


ONOMÁZEIN 34 (diciembre de 2016): 296-321

Andreea Rosca e Yvonne Baker de Altamirano:

Tracking down phrasal verbs: the case of up and down

\begin{tabular}{|c|c|c|c|}
\hline 9 & go down & $\begin{array}{l}\text { 1) happen (crime); 2) be sent to } \\
\text { prison; 3) lose, be defeated or } \\
\text { even die }\end{array}$ & $\begin{array}{l}\text { 1) Hostage exchange goes down at midnight } \\
\text { [S02E18] } \\
\text { 2) Young Mr. Addison is going down for } \\
\text { both murders [S03E19] } \\
\text { 3) She was strangled, but she went down } \\
\text { with a fight [S04E20] }\end{array}$ \\
\hline 10 & turn up & $\begin{array}{l}\text { 1) find or be found } \\
\text { unexpectedly, discover; 2) to } \\
\text { fold }\end{array}$ & $\begin{array}{l}\text { 1) You threatened a guy. Then he turns up } \\
\text { dead. [S02E11] } \\
\text { 2) But the way they were turned up makes me } \\
\text { think that someone went through and } \\
\text { emptied them. [S04E16] }\end{array}$ \\
\hline 11 & open up & $\begin{array}{l}\text { 1) open a locked door, } \\
\text { container, or building; 2) talk } \\
\text { more about your personal } \\
\text { feelings and experiences; 3) } \\
\text { start sth }\end{array}$ & $\begin{array}{l}\text { 1) NYPD, open up! I have an arrest warrant } \\
\text { for Jamie Ruiz. NYPD! [S03E07] } \\
\text { 2) She knows me. I might be able to get her } \\
\text { to open up. [S02E21] } \\
\text { 3) You intend on opening up an investigation } \\
\text { on my campaign with two weeks left until the } \\
\text { election? [S01E04] }\end{array}$ \\
\hline 12 & take down & $\begin{array}{l}\text { 1) hit or shoot sb so that they } \\
\text { fall down; 2) remove sb from a } \\
\text { prominent position }\end{array}$ & $\begin{array}{l}\text { 1) So he waited, probably left his car idling, } \\
\text { takes down his victim, popped his trunk, put } \\
\text { her in, drove away, body on board. [S02E17] } \\
\text { 2) [...] if the feds take down the Spolanos, } \\
\text { then the other families can take over their } \\
\text { territories. [S01E10] }\end{array}$ \\
\hline 13 & cover up & $\begin{array}{l}\text { 1) put sth over sth else so that it } \\
\text { cannot be seen; 2) prevent } \\
\text { people from discovering } \\
\text { mistakes or unpleasant facts }\end{array}$ & $\begin{array}{l}\text { 1) I'm sure you wouldn't want to be seen } \\
\text { talking to the cops, so as a courtesy, I'm } \\
\text { going to let you cover up with my jacket. } \\
\text { [S03E22] } \\
\text { 2) Murdered his sister and killed two more } \\
\text { people to cover up the crime. [S01E01] }\end{array}$ \\
\hline 14 & dig up & $\begin{array}{l}\text { 1) take sth out of the ground by } \\
\text { digging; 2) discover secret or } \\
\text { forgotten facts by searching } \\
\text { very carefully }\end{array}$ & $\begin{array}{l}\text { 1) Vales got Glitch to dig up the } \\
\text { bodies.[S04E21] } \\
\text { 2) Castle and I will head to the studio and } \\
\text { see what we can dig up there. [S02E20] }\end{array}$ \\
\hline 15 & give up & $\begin{array}{l}\text { 1) stop doing sth that you do } \\
\text { regularly; 2) stop trying to do } \\
\text { sth; 3)deliver a wanted person to } \\
\text { authority; surrender oneself to } \\
\text { the police; 4) reveal information }\end{array}$ & $\begin{array}{l}\text { 1) When I started dancing I gave up thug } \\
\text { life. [S04E18] } \\
\text { 2) Dunn... give it up. Nobody has to die. } \\
\text { [S02E18] } \\
\text { 3) Do you think she would give up her } \\
\text { friends to the cops? [S01E08] } \\
\text { 4) He's Special Forces. We're trained for } \\
\text { this. Never to give up information. [S03E17] }\end{array}$ \\
\hline 16 & clean up & $\begin{array}{l}\text { 1) make a place tidy, leave no } \\
\text { evidence behind; 2) stop using } \\
\text { drugs }\end{array}$ & $\begin{array}{l}\text { 1) He cleaned up all types of dirt for Senator } \\
\text { Wellesley back in the day. [S02E08] } \\
\text { 2) Alison King Rehab Center. It's where all } \\
\text { the stars go to clean up. [S02E07] }\end{array}$ \\
\hline 17 & shut down & $\begin{array}{l}\text { 1) stop operating (business, } \\
\text { piece of equipment, etc.); 2) } \\
\text { stop talking }\end{array}$ & $\begin{array}{l}\text { 1) Susan runs towards the ticking bomb to } \\
\text { try to shut it down. [S01E08] } \\
\text { 2) We don't have any proof that he did it. I } \\
\text { mean, what if he shuts down and doesn't } \\
\text { talk? [S02E03] }\end{array}$ \\
\hline 18 & follow up & $\begin{array}{l}\text { 1) pursue or investigate (a } \\
\text { person, evidence, etc.) closely }\end{array}$ & $\begin{array}{l}\text { Have you followed up with the victim's sister } \\
\text { regarding the antique bullet? [S03E04] }\end{array}$ \\
\hline 19 & make up & $\begin{array}{l}\text { 1) invent an explanation in order } \\
\text { to deceive; 2) prepare or arrange } \\
\text { sth by putting different things }\end{array}$ & $\begin{array}{l}\text { 1) How do we know this guy's not making } \\
\text { this up? [S04E19] } \\
\text { 2) [...] let's make up a sketch, show it to Alex }\end{array}$ \\
\hline
\end{tabular}


ONOMÁZEIN 34 (diciembre de 2016): 296-321

Andreea Rosca e Yvonne Baker de Altamirano:

Tracking down phrasal verbs: the case of $u p$ and down

\begin{tabular}{|c|c|c|c|}
\hline & & together & $\begin{array}{l}\text { Peterman's family, see if they recognize the } \\
\text { killer. [S02E17] }\end{array}$ \\
\hline 20 & sit down & $\begin{array}{l}\text { 1) lower oneself to a sitting } \\
\text { position }\end{array}$ & I said sit down... now! [S02E16] \\
\hline 21 & blow up & $\begin{array}{l}\text { 1) explode or make explode; } 2 \text { ) } \\
\text { make a photograph bigger; 3) } \\
\text { not happen as expected and } \\
\text { causing a lot of problems }\end{array}$ & $\begin{array}{l}\text { 1) You provided him with enough C4 to blow } \\
\text { up half a city block. What was it for? } \\
\text { [S03E12] } \\
\text { 2) [...] tech was able to blow up and } \\
\text { enhance that ATM video. They're sending it } \\
\text { up now. [S03E20] } \\
\text { 3) [...] One misstep and it'll all blow up in } \\
\text { your face. [S04E12] }\end{array}$ \\
\hline 22 & beat up & $\begin{array}{l}\text { 1) hurt someone badly by hitting } \\
\text { or kicking them repeatedly }\end{array}$ & $\begin{array}{l}\text { Making you believe that Knox beat her up so } \\
\text { that we'd think she killed him out of self- } \\
\text { defense. [S02E09] }\end{array}$ \\
\hline 23 & calm down & 1) stop feeling upset, angry & $\begin{array}{l}\text { Sir, I'm gonna need you to calm down. } \\
\text { [S03E17] }\end{array}$ \\
\hline 24 & lock up & $\begin{array}{l}\text { 1) imprison or confine; 2) keep } \\
\text { or store securely }\end{array}$ & $\begin{array}{l}\text { 1) But what I can do is I can lock him up in } \\
\text { prison for the rest of his life. [S04E21] } \\
\text { 2) Only better than a mailbox, because it's } \\
\text { locked up inside a bank. [S04E07] }\end{array}$ \\
\hline 25 & pull up & $\begin{array}{l}\text { 1) get information to show on a } \\
\text { computer screen }\end{array}$ & $\begin{array}{l}\text { Factoring in the time it would have taken her } \\
\text { to get to her car, let's say she got there at } \\
\text { 3:45PM. Pull up all cell phone traffic for the } \\
\text { next } 15 \text { minutes. [S04E15] }\end{array}$ \\
\hline
\end{tabular}

